\title{
Roma Identity, Integration and Education. Comparative Research
}

\begin{abstract}
This paper is a report of some studies conducted by the author in the Roma community in the Czech Republic and Slovakia. After a brief introduction and characteristics of the surveyed group, the theoretical basis of the research and the methodological approach was presented. The project was supposed to be an attempt to show the difference between the education of Roma and of the dominant community in their country of residence. The research objective of the project was to identify the Roma perception of education and school duty, to identify and understand the relationship between the Roma identity and their relation to education and participation. Three areas were analysed: identities, culture, and education. The identification of their identities, their participation in culture and the education of the culturally dominant group are indicated. The conclusions concern the current situation of the Roma in these areas and possible recommendations or solutions for the future.
\end{abstract}

Keywords:

ethnic identity, Roma minority, education, culture, integration, multiculturalism

\section{INTRODUCTION}

Being the most numerous minority group in Europe, above all in Central Europe, Roma/Gypsies are, at the same time, the least known community. There are 6-12 million Roma dispersed around Europe with two-thirds living in Central and East-

Faculty of Ethnology and Educational Science in Cieszyn, University of Silesia in Katowice, Poland, E-MAIL: lukaszkwadrans@poczta.fm. 
ern Europe. The whole Europe should try to get to know them to understand them. The surveys problem seems to be essential for the whole region of Central Europe.

Theoretical consideration concern: Romanis, ethnic identity; integration and social (cultural) assimilation; multicultural education; minorities' culture; social changes; transformation; globalisation. There are introduced: the characteristic of Romanis ethnic group and the situation in which Gypsy people are now. There are also described conditions of participation of Romanis/Gypsies in culture and education of majority. The author presents the project which would be an attempt to show the differences in the understanding of the education by the Roma and the dominant community in their country of residence. The aim would be to identify a formal relationship to the educational system and own group. The author describes the elements of the identity of the Roma. He also indicates a possible approach to the use of theoretical and empirical research. That were monographic surveys with the usage of analysing technique of documents and literature but also qualitative techniques (narration interview, interview, active observation). The research trip (internships) to Czech Republic and Slovakia enabled the author to gather required knowledge that would be taken from archives and libraries (teaching plans and programs - official and alternatives; governmental plans and specific law regulation; documents about educational institutions, associations, organizations and social movements that are engaged or take part in Romanis/Gypsies' education). The interviews with Romanis/Gypsy leaders and people engaged in Romanis/Gypsy education also played a vital role here.

\section{ROMA ETHNIC IDENTITY}

In the text, we consistently tried to use the name "Roma" not in terms of its ethnic but rather political significance. Despite some negative language associations, the name "Gypsies" is still used for reasons of historical or substantive correctness. Without forgetting the group diversity of the described community, we use the name "Roma" in its political meaning, thus covering all Roma groups. We also know that some of them do not use this ethnic name.

Their ethnic boundary, based on the above dichotomy, is additionally regulated by Gypsy purity laws and expressed by the three following models (Mirga \& Mróz, 1994, pp. 269-270). The first model is based on the contrasts of "pure-impure" (Romanipen-Gadjipen) (Hancock, 1992). Name "gadje” (plural. "gadjo”) means 'stranger, no-Roma'. Romanis are pure since they know how to avoid contamination. Non-Gypsies are impure due to their constant violation of the Mageripen code 
(it marks borders of conduct permitted among Roma people). According to the second model, contamination relates only to the Gypsy community and is respected only within the Romani group. The Roma perceive the inappropriate behaviour of Gadje whilst considering the non-Gypsy population as neutral. People who can lead to the contamination of the Roma are, for example, midwives and doctors. The contamination theory plays an insignificant role according to the third model. Non-Gypsies are portrayed more as evil and dangerous rather than impure. Roma, on the other hand, is depicted as good and wise.

It is crucial that Roma lack a collective ethnic identity which only now is being reinforced by a small group of Gypsy elite. Their ethnic identity relates mainly to the non-Gypsies (Gadje). The contamination can occur on different levels, depending on a Roma group.

American romologist - Matt Salo (1979, pp. 73-96) listed the below criteria distinguishing the Roma from the Gadje: The first one - universal - characterizes all the Gypsy groups. It is the Gypsy kinship - membership inherited naturally, because of birth to Gypsy parents. It reflects a status of an individual in a social stratum. One can also become a member of a Gypsy community via brotherhood and mixed marriage. A child being born in a mixed marriage enjoys the full rights of a Gypsy. The second one reflects the contamination concept in the Gypsy culture, the concepts of appreciation and respect. Rejection of Gadje by the Gypsy community is caused by their disrespect of Romani cultural standards. The third criterion is related to the Romani language which symbolically separates the Roma from the Gadje who cannot speak the Romani language. The fourth one reflects the norms, resulting from a group structure and the links between its members, which exclude non-Gypsy from the social organization of the Roma community. The fifth criterion constitutes the Gypsy economic business activity with the Gadje considered fair game for exploitation. The sixth one reflects the external distinctive anthropological features perceived by the Roma as Gypsy, such as: outfits, specific gestures and so forth.

\section{THEORY OF IDENTITY BEHAVIOURS}

A theoretical concept that would allow to systematize the determinants of the Roma identity and could be applied in the description of its subsequent areas is Tadeusz Lewowicki’s (2001, pp. 161-164) Identity Behaviour Theory (TZT: Teoria Zachowań Tożsamościowych). Especially in a comparative context with the majority group, as Tadeusz Lewowicki claims that concentration on a chosen minority community 
deforms reality and makes it difficult to reach general patterns, conditions, relationships (Lewowicki, 1995). Referring to the criteria described above in the TZT, the first three areas appear to be relevant to Matt Salo's first, second and third element, but also to the fourth and sixth. Thus, they concern the determinants of historical fate, the distinctness of the institution, culture, language, customs, transmission of tradition, biological and racial categories, personality traits, stereotypes. The fifth element of the Roma identity seems to correspond to the fourth TZT area, for it concerns the economic sphere, the standards of life, the styles of economic activity. It is also important to refer to the fifth and sixth TZT areas, but this will require in-depth study of the proposed issues (Kwadrans, 2014, p. 215).

The social and cultural identity of the Roma is being transformed, which may be reflected in their increasing participation in the socio-economic and political life of the countries of residence. They are increasingly adapting to continuous change, which does not matter to their identity. Often among the Roma comes to doubling, tripling identity (e.g., Olaši Roma - Roma - Slovak or Czech Roma - Roma, European, Citizen of the World). Also, Jerzy Nikitorowicz assumes the possibility of many dimensions of identity, which indicates the ongoing process of shaping and operating in three dimensions: identity inherited and acquired, identities of roles and challenges, identity felt and realized (Nikitorowicz, 2009, p. 378).

Following this concept, identity is perceived as the open process, continuing and endless development in the process of interaction and experience of the social reality, which is often difficult and painful, exposed to failures in the face of changing values and personal models. A focus is on the tendency to "develop oneself”, uniqueness, self-reflection and system of self-knowledge. Existence of modern human being in the context of aims and values (theology and axiology) is multidimensional. On the one hand, the following spheres should be developed: biological, social, psychological, intellectual, cultural and material ones, etc. On the other hand, problems and needs characteristic for these spheres should be observed.

Identity, described in a group perspective, originates from the interaction with a group and the manner of defining oneself in the framework of belonging. Identity of the ones can be based on the community through the ages, on religion and speaking the same language (Nikitorowicz, 2007, p. 755).

Identity, described in cultural perspective according to Nikitorowicz, is the symbolic universe of the simultaneous and inseparable existence in a few dimensions. It is a relatively long-lasting and constantly developing self-concept, which is expressed in the identification with the specific cultural values. Nikitorowicz indicates that elements of identity are mutually dependent on each other and linked together. Therefore, identity is developed in a selected group under the impact of 
the specific culture. It is not possible to develop self-image, self-concept or selfidentity (affiliation) if there is not a reference to a group, significant people and cultural heritage (Nikitorowicz, 2009, p. 334-335). Identity has also originated from the sum of life experience after different situations previously experienced by a human being (Nikitorowicz, 2001, p. 80).

\section{SHORT CHARACTERISTIC OF ROMA GROUPS}

European Roma, for centuries, have been faithful to their traditions and cultural heritage. This is reflected not only in their cultivation of the Romani language, maintenance of Romani customs and active participation in the lives of ancestral and tribal communities but is also manifested in the group exclusivism and compliance with solely Gypsy communal forms of organization, systems of rules, code of conduct rather than with the mainstream - non-Gypsy structure. Similarly, to the representatives of majority populations, the Romanis are living in times of constant social changes and the development of civilization. Consequently, their identity has undergone various transformations provoked by globalization, European integration, political system transformations, educational reforms and more active participation of Romani students in the schooling process. The government programmes, for the Roma community not only in Czech Republic and Slovakia but also in other countries, focus on amelioration of the Romani educational situation and their occupational development. The Romani identity is not closed since it has been undergoing, to a certain extent, transformations like the changes transforming the identities of other communities.

Romanis are surely a heterogeneous ethnic group. The division into subgroups influences the Roma's comprehension of the surrounding environment. It can be easily noticed that tribal identities are being replaced by a broader concept of Romanihood - attempted to be defined in national categories. The Romani community has been subject to social transformations because of the Gypsy elite's concerted attempts to create a homogenous Romani identity. Romani inner integrity embodies the common elements of Roma identity and similarities between the Romani subgroups. The newly deconstructed identity is vital not only for the Romani elite. Borrowing solely symbolism from its predecessors aids the self-identification process of individuals or whole groups through the common language, tradition and cultural heritage. Gypsy group cohesion and their social behaviour are strictly regulated by the highly developed inner system of social control outlined in the code of conduct and represented by Gypsy institu- 
tions - "the Romani traditional jurisdiction" (the rules of mageripen, romanipen, manusipen). Transgression of taboo of mageripen leads to tainting. Romanipen marks the border of ethnicity, it is an interpretation of Roma tradition and is valid only inside community. Manusipen is humanity, preserving Roma moral values "written" in romanipen. There are different institutions within various Roma groupings. Some institutions are more democratic, represented by a kris (group of persons) in collective decision taking. The others are ruled by one leader (Śero Rom, Jonkaro) (Ficowski, 1985, pp. 175-199). Inner relations and social stratification are regulated not only by the hereditary caste status but also by personal traits of an individual person. The diversity of Romani ethnic identity depends on the length and intensity of the assimilation process conducted towards representatives of the Romani minority group. Most of the Roma communities are characterized by a high spatial mobility. Their family home - a cradle of Gypsy culture, place of meetings, Gypsy fortress - and oral transfer of customs, history and cultural traditions to the younger generation (oral culture), played an integral part in the preservation of Romani cultural traditions. The Romani language is still spoken in the traditional Gypsy home.

The Romanis form one cultural group around the world that is internally divided. The division occurred because of fundamental clan and tribal differences, traditional and modern nomadic practices, Gypsy dispersal and settlement in different countries. Romani existence next to the mainstream populations, with distinctive cultural traditions, religion, socio-political characteristics, also influenced the Romani identity. However, Roma remain largely unknown by the majority population. Their distinctness is reflected by group exclusivism and cultural ethnocentrism. Despite their subdivisions, Romani people have succeeded in retaining their inner integrity. One of its characteristic features is endogamy, the practice that facilitated the maintenance of Romani homogeneousness. Furthermore, Roma integration into a host society or even into the global population might lead to the creation of a universal Romani identity. The Romanis might also skip the phase of national identity formation and adopt a broader European identity or even head towards New Tribalism - the phenomenon which embodies the return to traditional elements of Romani identity.

Roma people divisions are also visible in Czech Republic. We can divide them into five different subgroups which considerably vary in numbers. The first three are newcomers who settled during the migrations after 1945. The first and biggest group is Slovakian Roma, otherwise called Servika Roma, Slovenska Roma, i.e., c. $65-75 \%$ of all Roma people. Such great amount of Slovakian Roma in Czech Republic is a result of many-years migration to Czech Republic in search of jobs 
and place to live in Czechoslovakia time. The second group are Hungarian Roma, ethnonym Ungrika Roma. They are 15-20\% Roma in Czech Republic. Wallachian Roma - Olaši (Vlachi, Vlachika Roma) are a small community. There are 10-15\% in the population of Czech Roma. They came from the territory of present-day Romania. The least numerous group are Czech Roma, sometimes divided into Czech and Moravian Roma and German Roma - Sinti. Both communities had been living on the territory of Czech Republic before the Second World War, but the majority were murdered by German Nazis. Czech Roma are descendants of several hundred people who survived the extermination. They are mostly assimilated group, especially as far as language is concerned.

In present-day Slovakia, we can also divide Roma society into sub-groups. Similar groups inhabit territory of Czech Republic. The biggest community are Slovakian Roma people. Distinct line of the division and Olaši Roma manifests itself on different level of upholding tradition and language and different ways of living and dwelling. Other groups have little percentage of Roma people in Slovakia.

Up to the present, no reliable data have been gathered which would show a considerable fluctuation in the size of Roma population and include a thorough analysis of their characteristic demographic features.

Table 1. The Roma population in the Czech Republic (the $20^{\text {th }}$ and $21^{\text {st }}$ centuries)

\begin{tabular}{|c|c|}
\hline Year & Roma population \\
\hline 1930 & $227^{y}$ \\
\hline 1947 & $16,752^{\mathrm{x}}$ \\
\hline 1970 & $60,279^{y}$ \\
\hline 1980 & $88,587^{\mathrm{y}}$ \\
\hline 1989 & $150,000^{\mathrm{y}}$ \\
\hline 1991 & $32,903^{\mathrm{y}}$ \\
\hline 2001 & $11,746^{\mathrm{y}}$ \\
\hline \multirow{2}{*}{2011} & $150,000-300,000^{\mathrm{x}}$ \\
\hline
\end{tabular}

Key: ${ }^{x}$ - demographic estimates; ${ }^{y}$ - census data/official data. References: Barany, 2002, p. 126; Kalibová, 2001, pp. 125-132; Langhamrová \& Fiala, 2003, pp. 23-32; Sčítání lidu v Republice československé ze dne 1. prosince 1930; Sčitání lidu, domů a bytů 1991. Základní údaje za republiky, kraje a okresy - Česká republika; Sčitání lidu, domů a bytů 2001; Český statistický úrad. http://www.czso.cz; G. Šamanová, Národnost ve sčitání lidu v českých zemích, http://www.cvvm. cas.cz/upl/nase_spolecnost/100023s_Samanova-narodnost.pdf (accessed: July 24, 2017). References: Census of people in the Republic of Czechoslovakia from the $1^{\text {st }}$ of December 1930. Registration of people, houses and flats 1991. The basic details for the republic, regions and counties - The Czech Republic; Registration of people, houses and flats 2001; Czech Statistical Office. 
Table 2. The Roma population in Slovakia (the $20^{\text {th }}$ and $21^{\text {st }}$ centuries)

\begin{tabular}{|c|c|}
\hline Year & Roma population \\
\hline 1930 & $31,188^{y}$ \\
\hline 1947 & $84,438^{y}$ \\
\hline 1970 & $159,275^{y}$ \\
\hline 1980 & $199,863^{y}$ \\
\hline 1989 & $253,943^{y}$ \\
\hline 2001 & $75,802^{y 1}$ \\
\hline 2011 & $89,920^{y}$ \\
& $350,000-500,000^{x}$ \\
\hline \multirow{2}{*}{2001} & $105,738^{y}$ \\
\hline
\end{tabular}

Key: ${ }^{\mathrm{X}}$ - demographic estimates; ${ }^{\mathrm{y}}$ - census data/official data; ${ }^{1}-77,269$ persons declared they spoke Romani language at home. References: Barany, 2002, p. 126; Kalibová, 1990, pp. 219-223; Kozmová, 2004; Vaňo \& Haviarová, 2002, pp. 475-502; Vaňo, 2001.

Table 3. The Roma population in the Czech Republic and Slovakia - comparative overview

\begin{tabular}{|c|c|c|}
\hline Data & The Czech Republic (2001) & Slovakia (2001) \\
\hline Census data & $\begin{array}{c}11,746 \\
\text { (0,11\% of total Czech population) }\end{array}$ & $\begin{array}{c}89,920 \\
\text { (1,65\% of total Slovak population) }\end{array}$ \\
\hline $\begin{array}{l}\text { Demographic } \\
\text { estimates }\end{array}$ & $\begin{array}{c}150,000-300,000 \\
(1,42 \%-2,84 \% \\
\text { of total Czech population) }\end{array}$ & $\begin{array}{c}350,000-500,000 \\
(6,42 \%-9,16 \% \\
\text { of total Slovak population) }\end{array}$ \\
\hline $\begin{array}{l}\text { Overall number of } \\
\text { Roma population }\end{array}$ & $10,532,770$ & $5,455,000$ \\
\hline
\end{tabular}

Source: Barany, 2002, p. 126; Davidová, 2004, pp. 24-49; Vaňo \& Haviarová, 2002, pp. 475-502.

\section{ROMA EDUCATION}

Romani education (Romani ethnic group education and so forth) relates mainly to the educational initiatives of the host countries. The activities that comply with the official education system applicable in a country embrace schooling and education of Romanis, educational activity of Non-Governmental Organizations, other educational institutions, Romanis and their minority associations. The programmes also comprise all the initiatives familiarizing the mainstream population with the facts related to the Romani lifestyle and situation. The above understanding of "Roma education" fully reflects the concept of intercultural education and it cannot be restricted solely to the educational programme carried out but Romanis themselves for their own ethnic group (Kwadrans, 2011, p. 7). 
Roma people are the most defenceless group and the most unwanted at the same time among European minorities. We could observe: growing pauperization of some part of the Romanis, trends to isolating them by national society, unemployment, aggravating health situation, still low level of education among Romani children and youth. Roma Education after 1989 was still in bad condition. Almost half of 8-12 million Roma people in Europe were in school age. 30-40\% of children do not get elementary education. Roma pupils have still problems with reading and writing. Usually they do not continue education in high school. Almost $54 \%$ of adult Roma people in Europe are illiterates, in some regions even 80-100\%.

\section{SHORT REPORT FROM RESEARCH}

Due to the limited form of the article, the author left out more detailed description of the unit results of scientific research. The extensive part containing conclusions and summary contains a detailed description of the results.

Project goal is: Indication of differences in the presented attitude towards education and cultural differences and the sense of identity of the Roma. Central area of interest is Roma identity, its transformation, attitude to education. Conclusions from the research conducted in Poland were the basis for the formulation of the research problem: What is the feeling of Roma identity and their attitude towards education? Can the relationship between cultural identity and Roma identity and their relation to education and school fulfilment be recognized? Identity is central to research interest. The purpose of the research: to indicate the differences in the attitude towards education and cultural differences and the sense of identity of the Roma. Adoption of relative dynamics: diagnosis for 2 groups: 1) students in segregation and integration education; 2) youth and adults.

Main problem is: Can the relationship between cultural identity and Roma identity and their relation to education and participation be seen? 3 diagnostic problems corresponding to theoretical threads: Problems related to Roma culture; Roma Identity Problems; Problems related to Roma education. Specific problems (Culture): 1. Are the Roma aware of their cultural differences as they understand it? 2. Do the Roma engage in social and cultural life of their own or majority groups and how do they assess their activity? 3. What experiences are there in Roma culture? 4. What attitude to their own and what other people declare / show Roma and to what extent? 5. Do they favour their own cultural group? 6. In which direction is the acculturation of the Roma heading, the culture of its own or domi- 
nant? 7. What cultural patterns are conveyed in a homogeneous and heterogeneous family? Specific problems (Identity): 1 . What are the identity behaviours of the Roma? 2. How do the Roma perceive themselves and their behaviour? 3. What - in the opinion of the respondents - are the criteria for being a Roma? 4. What identity profiles do they accept (one, two, multi-dimensional)? 5 . What is the dynamics of identity formation in individual Roma groups? 6. What is the dynamics of identity formation in Roma and mixed families? 7. What elements of identities are common, different for representatives of Roma groups and for the country of residence? Specific problems (Education): 1. Do the Roma engage in group education or do they work in majority-group education and how do they assess their activity? 2. What are the experiences related to functioning in education declared by the Roma? 3. To what extent does the country of residence of the Roma condition their participation in education? 4. How does Roma schooling fulfilment in the studied countries take place? 5. How do Roma perceive education and school duty (help, assistants, programs)? 6. What is the participation of Roma children in education (network of schools, number of students, school achievements)? 7. To what extent do Roma get knowledge about their own culture at school? Specific problems (Identity and participation in culture and education): 1. How do identity profiles fit into the majority culture? 2. How do identity profiles assume participation in education? 3. To what extent does the identity change from tribal to national? 4. To what extent does the identity change from one-dimensional to multidimensional?

There is also a description of Roma participation in the culture of majority societies, the implementation of school attendance and participation in education. It seems important to emphasize the educational thread, the institution, the school network, the number of pupils, their participation in education, attendance, school achievement. The project is an attempt to show the difference between Roma education and the dominant community in their country of residence. The purpose of the project was to identify the Roma's attitude towards education and the school duty.

The study was conducted: in Slovakia (I-VI 2015) in: Nitra - Orechov Dvor, Koszyce - Lunik, Poprad - Hranovnica, Letanovce, Hrabusice, Zehra, Hrusov, Bratislava, Dunajska Streda; in the Czech Republic (III-V 2016) in: Zlin, Prague, Straz pod Ralskom, Hradec Kralove, Usti nad Labem.

We have experienced problems in conducting research. They were related to: specificity of the group, difficulty entering the group, problems of cultural differences, language problems, communication skills, technical - exclude the use of quantitative approach, transition from individual to collective interview, 
researcher relationship - investigated, stereotypes, subjectivity, ethical implications, intercultural competence of the researcher.

Studies were conducted in the towns and villages (also of the Roma settlements) in the Czech Republic and in Slovakia. The selection of participants reflected the group divisions and the size of this community in both countries. Most respondents, interviewees were male. This was due to cultural reasons. Often interviews went from individual to collective. Most of the respondents were characterized, although in the labour mobility declarations. Accepted identity profiles were from one dimensional to multidimensional. The latter was declared more often. They were denominated in groups, family, and world citizenship. There were no significant differences between heterogeneous and homogeneous families.

During the study, the multidimensionality of Roma identification was noted, discovery of a certain outbreak of ethnicity. This could be related to the mobilization of group elites. Attempts to adapt and integrate with the majority may be due to the significant role of the European Union aid programs. Otherwise, the Roma declare their group identification during censuses (they are reluctant to admit their identity) and otherwise they can participate in projects and be their beneficiaries.

Researchers have found that, despite being treated by Roma as a majority of the population as a cultural group, Roma themselves declare little awareness of cultural or social differences. Stereotypes perceive their own culture. They point to music, dance, singing, folklore. Acceptance for cultural differences, Gadjos otherness, is noticeable

During the study, the positive thinking of the Roma about school segregation was revealed. They have a sense of security that children learn in school with other members of the group. They do not perceive the role of classes, schools of integration character. Among the Roma, there appears a low educational awareness, negative school experience (in the adult group). The respondents positively assessed school attendance and the value of education. They pointed out the lack of opportunities to deepen their knowledge of self-help in formal education.

\section{CONCLUSIONS}

Socialist governments of these countries have made unsuccessful efforts to facilitate a process of assimilation of Roma people. As a result, during transformation (during more than 25 years) Roma society was one of the weakest educated and the most neglected group in Czech Republic and Slovakia. Education policy in these countries is not satisfactory enough because of: ideals of multicultural education, 
the civilization development and an economical status of Roma people. Low level of education among Roma, the lack of job qualifications, difficult living conditions generate new problems and intensify social marginalization. The education can help Roma people in their economic situation as well as in more active social life. One of the biggest problems for Roma, besides low educational consciousness and low level of education, is the school segregation - classes and schools only for Romany or very common special schools.

Both of these two countries have worked out their own educational and government programs, which are different from each other in moment of their initiation, in their character and the way of realization.

Necessary conditions to change unsatisfactory reality are: a cooperation, an exchange of experiences and facts about Roma's education; equal educational chances for Roma's students (nursery education, pre-primary classes); improvement of social situation of Roma's children and their families (scholarship system); elimination of any discrimination, intolerance and racism acts at schools; liquidation of school segregation, learning in integration classes constructed by age and intellectual level; developing such institution as Romani assistant and teacher supporter; multicultural education programs at schools; an activity of Romani elite into creation and realization educational policy in their society; an increase of educational consciousness among Roma's parents and children.

The project has exploratory significance for this part of knowledge. It can be very useful source for: theoreticians (dealing with multicultural education), practitioners (Roma assistants, teachers supporting Romani/Gypsy activists, institutions engaged in favour of Romani/Gypsy Society), and authors of governmental programs, which are to change Romanis/Gypsies’ situation.

It is also important that representatives of the Romani community, Roma leaders, members of various organizations and associations engaged in the Roma educational process share their opinions about relevant changes. Moreover, everybody can benefit from the expertise and help of various experts on the education of ethnic and national minorities. Educated Romani elite should be engaged in the creation and management of the educational policies for their community. Roma students and university graduates should be supported throughout their university career. After the graduation, they should be subsequently engaged in different government programmes and projects implementation for their own community group.

Roma children need to be supported in kindergarten education, reception classes (0-level) and encouraged to study in mainstream schools, situated close to their place of living. Roma educational organizations could support these practices (such NGOs already exist in the two researched countries). 
It is necessary to raise educational awareness of Romani children and their parents. The whole process of engaging Romani families in their children education, adult education, pointing at positive role models, can be done with the help of public media, but first, in cooperation of local organizations. Roma parents should be involved in their children's school life. School authorities and teachers can play here an important role in creating a friendly, unbiased environment for Roma children. Better educated and qualified teachers and educators, specializing in the work with Roma children, should be supported and motivated by pay incentives and other forms of promotion.

The author of this paper is aware that limited character of his work did not allow him to develop many issues in detail (difficulties related to the Roma children school motivation, school attainments analysis). Therefore, presented outcome might seem to be too general. However, because it is a complex problem, it can be further developed and analysed in detail. The publication is a description and an evaluation of the Romanis' educational situation and constitutes the comparison of the educational Romani reality with the Roma's and non-Roma's expectations towards the education policy implemented by the administrative authorities.

\section{References}

Barany, Z. (2002). The East European Gypsies. Regime Change, Marginality and Ethnopolitics. Cambridge: Cambridge University Press.

Davidová, E. (2004). Romano drom. Cesty Romů 1945-1990. Zmeny v postaveni a způsobu života Romů v Čechách, na Moravě a na Slovensku. Olomouc: Vydavatelství Univerzity Palackého.

Ficowski, J. (1985). Cyganie na polskich drogach. Kraków: Wydawnictwo Literackie.

Hancock, I. (1991. The East European Roots of Romani Nationalism. In: D. Crowe, J. Kolsti (Eds.), The Gypsies of Eastern Europe (pp. 133-150). Armonk-London-New York: M.E. Sharpe.

Kalibová, K. (1990). Prognóza romské populace v ČSFR do roku 2005. Demografie, 32(3), pp. 219-223.

Kalibová, K. (2001). Romové v Evropě z pohledu demografie. Demografie, 43(2), pp. 125132.

Kwadrans, Ł. (2011). Education of the Roma in the Czech Republic, Poland and Slovakia - gap confrontation between expectations and reality - comparative research. Wrocław: Wydawnictwo Fundacji Integracji Społecznej PROM.

Kwadrans, Ł. (2014). Transmisja kultury w rodzinie romskiej i mieszanej - adaptacyjne sukcesy i porażki. In: J. Nikitorowicz, J. Muszyńska, B. Boćwińska-Kiluk (Ed.), Od wielokulturowości miejsca do międzykulturowości relacji społecznych. Współczesne strategie kreowania przestrzeni życia jednostki (pp. 206-223). Warszawa: Wydawnictwo Akademickie Żak. 
Langhamrová, J., \& Fiala, T. (2003). Kolik je vlastně Romů v České republice?. Demografie, 45(1), pp. 23-32.

Lewowicki, T. (1995). O badaniach społeczności pogranicza - od parcjalnych opisów ku elementom teorii zachowań tożsamościowych. In: J. Nikitorowicz (Ed.), Edukacja międzykulturowa. W kręgu potrzeb, oczekiwań i stereotypów (pp. 13-27). Białystok: Wydawnictwo Uniwersyteckie Trans Humana.

Lewowicki, T. (2001). Szkic do teorii zachowań tożsamościowych. In: T. Lewowicki, \& E. Ogrodzka-Mazur (Eds.), W poszukiwaniu teorii przydatnych w badaniach międzykulturowych (pp. 159-165). Cieszyn: Uniwersytet Śląski w Katowicach, Filia w Cieszynie.

Mirga, A., \& Mróz, L. (1994). Cyganie. Odmienność i nietolerancja. Warszawa: PWN.

Nikitorowicz, J. (2009). Edukacja regionalna i międzykulturowa. Warszawa: Wydawnictwa Akademickie i Profesjonalne.

Nikitorowicz, J. (2017). Etnopedagogika w kontekście wielokulturowości i ustawicznie kształtującej się tożsamości. Kraków: Impuls.

Nikitorowicz, J. (2001). Pogranicze. Tożsamość. Edukacja Międzykulturowa. Białystok: Trans Humana.

Nikitorowicz, J. (2007). Tożsamość - istota, geneza, wymiary. In: T. Pilch (red.), Encyklopedia pedagogiczna XXI wieku, Vol. 6, Warszawa: Wydawnictwo Akademickie Żak.

Salo, M. (1979). Gypsy Ethnicity: Implications of Native Categories and Interaction for Ethnic Classification. Ethnicity, 6(1), pp. 73-96.

Vaňo, B. (2001). Demografická charakteristika rómskej populácie v SR. Bratislava: INFOSTAT -.Výskumné demografické centrum [Research demographic centre].

Vaňo, B., \& Haviarová, E. (2002). Demografické trendy rómskej populácie. In: M. Vašečka (Ed.), Čačipen Pal o Roma. Súhrnná správa o Rómoch na Slovensku (pp. 475-502). Bratislava: Inštitút pre verejné otázky.

\section{Online Sources}

Kozmová, G. (2004). Rómsky problém na Slovensku. Slovenská politologická revue, 4, pp. 1-4. Retrieved from: https://www.ceeol.com/search/viewpdf?id=5617 (accessed: November 21, 2017).

Sčítání lidu v Republice československé ze dne 1. prosince 1930; Sčítání lidu, domů a bytů 1991. Základní údaje za republiky, kraje a okresy - Česká republika; Sčítání lidu, domů a bytů 2001; Český statistický úřad. http://www.czso.cz; G. Šamanová, Národnost ve sčítání lidu $v$ českých zemích, http://www.cvvm.cas.cz/upl/nase_spolecnost/100023s_Samanovanarodnost.pdf (accessed: July 24, 2017). 